\title{
Fysisk aktivitet og helse
}

For over 2000 år siden skrev Hippokrates "Whoever wishes to investigate medicine properly, should proceed thus: ...to consider (...) the mode in which the inhabitants live, and what are their pursuits, whether they are fond of drinking or eating to excess, and given to indolence, or are fond of exercise and labor..." (1). Fysisk aktivitet $\mathrm{i}$ arbeid og fritid er også i dag faktorer som er av betydning for folks helse og sykdomsrisiko, og fysisk inaktivitet utgjør en stor helseutfordring i det meste av den vestlige verden (2). Forskning på helseeffektene av fysisk aktivitet er likevel en relativt ny vitenskap, både internasjonalt og i Norge. Fagområdet har imidlertid hatt en sterk vekst de senere år, og involverer en rekke institusjoner, fagmiljø og forskere.

Én sentral fagperson i norsk epidemiologisk forskning var professor Peter F. Hjort (1924-2011). Hjort ble ansatt som den første rektor ved universitet $\mathrm{i}$ Tromsø $\mathrm{i}$ 1972, og var gjennom hele sitt liv genuint opptatt av fysisk aktivitet og helse. Som gjesteredaktører for dette nummeret av Norsk Epidemiologi, henvendte vi oss våren 2010 til professor emeritus Hjort. Han ble særskilt invitert til å skrive en artikkel i temanummeret. Vi fikk et vakkert håndskrevet brev i retur, hvor han var svært takknemlig for å bli spurt. Han måtte dessverre takke nei da han var på slutten av livet. Til tross for sin høye alder var Peter F. Hjort faglig aktiv til det siste. Han skrev med elegant letthet om blant annet fysisk aktivitet og eldres helse, og hevdet at det epidemiologisk var en klar sammenheng mellom fysisk aktivitet og funksjonsdyktighet, sykelighet og dødelighet.

Da Knut Westlund (1923-2007) ble ansatt som professor ved Universitetet i Tromsø i 1972, var dette som den aller første professor i epidemiologi i Norge. Han bidro til faglig utvikling og veiledet mange studenter og stipendiater. En av Westlunds studenter var Lars J. Vatten. Vatten tok sin doktorgrad i epidemiologi i Trondheim 1990, og ble i 1996 professor i epidemiologi ved NTNU. Professor Vatten har videreført sitt store engasjement og sine kunnskaper innen epidemiologien til mange. Han var den første som underviste fysisk aktivitets-epidemiologi ved Universitet i Trondheim for mer enn 20 år siden. Han la også grobunn for at fysisk aktivitets-epidemiologi er et eget fagområde på Institutt for bevegelsesvitenskap ved NTNU. To av gjesteredaktørene jobber i dag ved dette instituttet.

Fysisk aktivitets-epidemiologi er blitt anvendt som en egen betegnelse på populasjonsbasert forskning med fysisk aktivitet som enten eksponering eller utfall, men omfattes av de samme metodiske prinsipper og krav til studiedesign, datakvalitet og statistiske analyser som er sentrale i all epidemiologisk forskning. Metodene som er tilgjengelige for å måle fysisk aktivitet og fysisk form er i stadig utvikling, i takt med den teknologiske utviklingen, og muliggjør at objektive mål også kan anvendes i store utvalg egnet for epidemiologiske studier. I dette nummeret av tidsskriftet presenterer Hjellset og Høstmark et arbeid hvor både selvrapportert og objektivt målt fysisk aktivitet er benyttet for å studere sammenhengen til metabolske risikofaktorer blant pakistanske innvandrerkvinner i Oslo. Overvekt og fedme omtales ofte som en konsekvens av inaktivitet, og sammenhengen mellom fedme og risiko for sykdom og død er blitt vurdert i en rekke observasjonelle studier. De metodiske utfordringene til slike studier blir presentert og diskutert i artikkelen til Flanders og Augestad. Flere av momentene som diskuteres har relevans også for andre epidemiologiske problemstillinger; blant annet at effekten som skal studeres må defineres tydelig. Dermed blir definering av eksponering og utfall sentralt. Nerhus og kolleger presenterer i sin artikkel en redegjørelse for hvordan ulike begreper relatert til fysisk aktivitet kan forstås og anvendes.

Stadig mer forskning viser at fysisk aktivitet har gunstige effekter på folks helse, og kan være relatert til redusert risiko for en rekke sykdommer og tilstander. Fløtnes og kolleger presenterer i sin studie av ungdom som deltok i Helseundersøkelsen i Nord-Trøndelag (HUNT) data på fysisk aktivitetsnivå, deltagelse i sport, og kroppsoppfatning relatert til risiko for psykiske plager. Videre presenterer Gudmundsdottir og kolleger resultater fra en longitudinell studie av fysisk aktivitet og menstruasjonsforstyrrelser blant voksne kvinner i HUNT, mens Morseth og kolleger har skrevet en oversiktsartikkel om hvordan ulike typer fysisk aktivitet kan påvirke bentetthet.

I de tre neste artiklene som har fått plass i dette nummeret av tidsskriftet er vi tilbake til mer tradisjonelle effekter av fysisk aktivitet; det vil si de som er knyttet til hjertesykdom og kardiovaskulære risikofaktorer. I alle tre artiklene står objektive målinger av fysisk aktivitet og fysisk form sentralt. Solbraa og kolleger presenterer data på fysisk aktivitet og kardiorespiratorisk fitness, samt risikofaktorer for hjertekarsykdom i et utvalg av 40-55 åringer i Sogn og Fjordane, mens Emaus og kolleger har brukt data fra Tromsø-studien til å studere hvilken sammenheng kardiorespiratorisk fitness og kroppsmasse har til blodtrykk. Det er kjent at prevalensen av diabetes blant pakistanske invandrere til Norge er høy, og Andersen og kolleger presenterer i sin artikkel data på fysisk aktivitet, kardiorespiratorisk fitness og metabolsk syndrom blant pakistanske menn i Oslo, og hvordan disse variablene er relatert til deltakernes yrke.

I den siste artikkelen i dette temanummeret beskri- 
ver Rehn og kolleger et spennende pilotprosjekt i SørTrøndelag. Her har man som utgangspunkt at fysisk aktivitet har kjente gunstige effekter som kan bedre helsen og forebygge sykdom, men at kunnskapen om hva som kan gi økt fysisk aktivitet i befolkningen er mangelfull. Formålet med prosjektet er å skape en koordinert samhandling om tiltak som kan øke aktiviteten $\mathrm{i}$ alle lag av befolkningen, og derigjennom bedre folkehelsen.

Til slutt vil vi takke for muligheten til å redigere dette nummeret av Norsk Epidemiologi, og spesielt for det gode samarbeidet vi har hatt med både forfattere og referee'er for å få dette i havn. Vi har hatt stor glede av å arbeide med de innsendte artiklene, og håper også du som leser finner noe som fanger interessen.

\section{Referanser}

1) http://classics.mit.edu/Hippocrates/airwatpl.html 2) http://www.who.int/dietphysicalactivity/en/

\section{Gjesteredaktører}

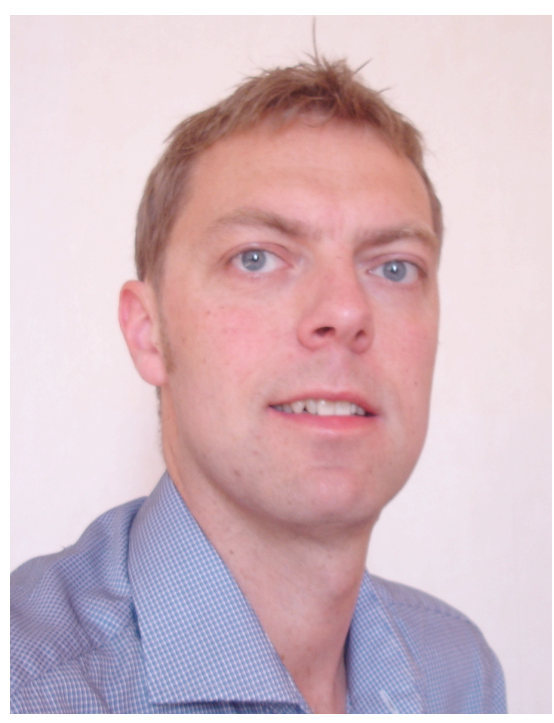

\section{Tom Ivar Lund Nilsen}

Institutt for bevegelsesvitenskap, NTNU, Trondheim

tom.ivar.lund.nilsen@svt.ntnu.no

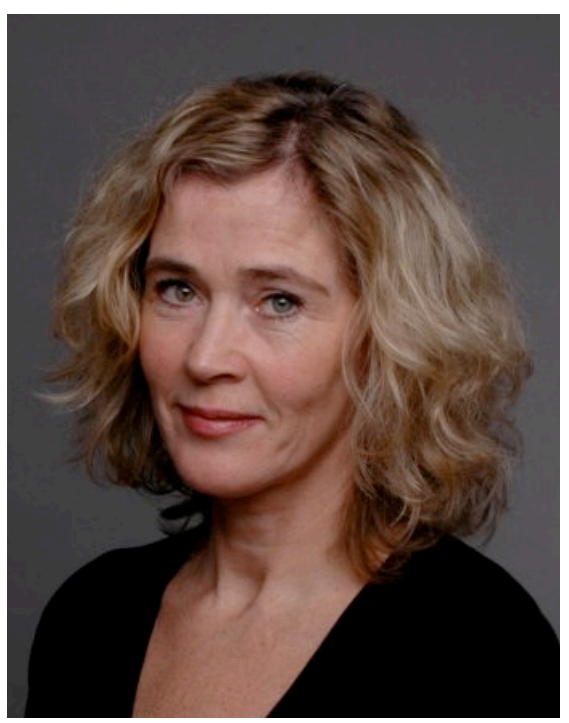

\section{Liv Heide Magnussen}

Uni Helse, Bergen

liv.magnussen@uni.no

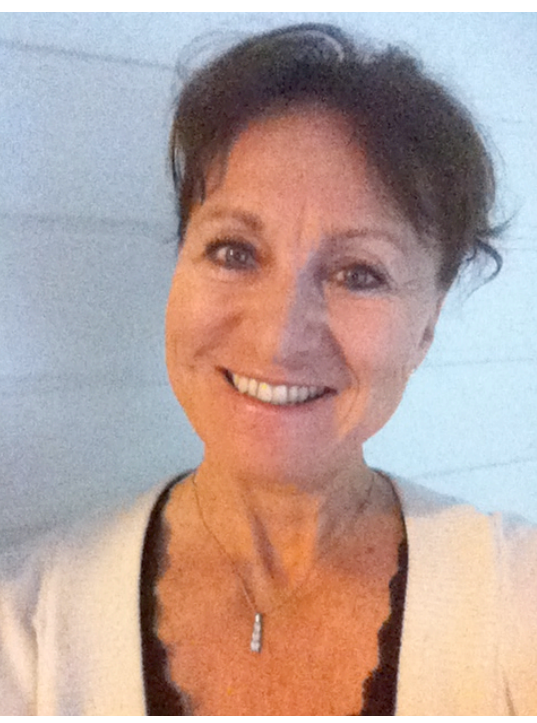

\section{Liv Berit Augestad}

Institutt for bevegelsesvitenskap, NTNU, Trondheim

liv.berit.augestad@svt.ntnu.no 